\title{
Indonesia's Millennial Generation Education Progress during Covid-19
}

\author{
Muhammad Naufal Priyotomo ${ }^{1}$, Moses Glorino Rumambo Pandin ${ }^{2}$ \\ Universitas Airlangga \\ muhammad.naufal.priyotomo-2020@,fib.unair.ac.id, moses.glorino@fib.unair.ac.id
}

\begin{abstract}
Because of the covid-19 pandemic, world development has de-escalated, and some have come to a halt because there are many new problems that this era never faced before. Especially in Indonesia's education, every student in this millennial era who is already used to face-to-face lectures and teachers and professors are going through massive changes where every task will be done virtually. These actions are being done to prevent the spread of Covid-19. With online meetings, there will be many changes in the curriculum to find an effective way of studying, and the former curriculum will not fit because it was made for the offline lecture. Also adapting to it will take time. This article will bring up Indonesia's education progress in this era while Covid-19 pandemic is happening and give an insight on how to anticipate this problem. Questions that arise from this topic are the effect of government effort on holding the pandemic, is it safe if school will be opened soon, and how education after this pandemic is. This research uses literature review methods where it's done by search, gather, compile and interpret data that is being used. The data are from the latest research, namely from 2019 to 2021 published through Google Scholar, totaling 11 articles, and few online news to keep relevancy of the topic. The results of this study indicate that Covid-19 produces a change that is worse than the good. Even so, the government has allowed face-to-face and online learning according to the consent of students and parents. Thus, the community, especially students, teachers, and others, are expected to uphold education even though it is required to adapt according to existing protocols. From the research, literature review methods proved to be effective to study this topic while Covid-19 is happening to keep safety measures, but it does not give many details and specific information well. This method is recommended to researchers who don't want to risk their life by being exposed to the pandemic.
\end{abstract}

Keywords: Covid-19, Millennial, Education Progress

\section{INTRODUCTION}

Education comes from the Latin "Eductum", which means development from within and development. Etymologically education is a development process within the individual (9). In "Kamus Besar Bahasa Indonesia" (KBBI), education is changing the attitudes and behavior of a person or group of people to mature humans through teaching and training efforts, the process, the way, the act of educating. Education is the right of every Indonesian citizen (WNI) as stated in Article 31 Paragraph 1 of the 1945 Constitution of the Republic of Indonesia, which reads, "every citizen has the right to get education". This article serves to assist the development of Indonesia with government supervision so that all Indonesian citizens can get an education as a whole.

This pandemic is caused by a virus called Covid-19, a new variant of SARS (Severe Acute Respiratory Syndrome) that was first discovered in Wuhan, China, on December 31, 2019. This virus causes 
respiratory problems, lung infections and can even kill people. Covid-19 is always developing until recently, CNN broadcasted it, and other news has found a new type of virus from India and has just entered Indonesia. According to data from the WHO (World Health Organization), this virus continues to take its toll; at this time, it has claimed 3,412,032 victims, according to data from the WHO (World Health Organization).

With the circulation of this virus, almost worldwide face challenges in various aspects of the country, especially education. In Indonesia, to inhibit the movement of the virus, the government has issued various policies, such as Large-Scale Social Restrictions (PSBB), Physical distancing, and isolation. Also advised people to stay at home and do all work, study and worship at home. This condition obliges the government to urge all educational institutions to innovate in examining ways of learning to adapt to current conditions. According to the institute provided, one form of adaptation of an institution in learning is the usage of online classes through virtual meetings with cameras.

This decision can also cause new problems from an economic aspect where the internet, electricity, and equipment are difficult to reach. Learning methods in the environment are not usually used to teach formal education for school residents. Then character building with Citizenship Education and Religious Education becomes more difficult because usually, what teachers can teach students through in-person meetings can be done at school. However, with the existence of Covid-19, students can only learn theory, but it lacks in its application.

Although formal education in Indonesia is carried out in schools for 12 years, the family or parents are the places for a child's primary education. During Covid-19, parents can monitor, teach, and socialize with their children with more free time if they do their activities online. WHO (World Health Organization) has issued guidelines on assisting children during this quarantine to continue so that care can be more structured and positive in activities at home.

The purpose of this study is to provide information to readers about the effects of Covid-19 on education in Indonesia in this millennial era, which has greatly changed the habits of learning in general and provides views on students and residents of the education environment to anticipate the uncertainty of this pandemic. The solution is in the form of choices and activities that can be done on adapting to study at this time and a reflection on the future. Based on the compiled introduction, it looks that Covid-19 has greatly changed the realm of education. Then the questions that arise from the description are: (1) How is the effect of the efforts made by the government to contain Covid-19?; (2) Is it safe within this period for school to reopen?; and (3) How is Indonesia in education's future with this pandemic? Thus, in this article, the author will explain the journey of education in Indonesia during the Covid-19 pandemic. 


\section{METHOD}

This article uses qualitative approach literature review method. The steps of research successfully done by gathering data (11). This study performs data classification based on the research formula (12). Then, data processing and citations are carried out to be displayed as results or research findings, abstracted the data to obtain complete information, lastly interpreted to get ideas for drawing conclusions. In short, the steps of research as follows:

Table 1. Literature Review Method Steps

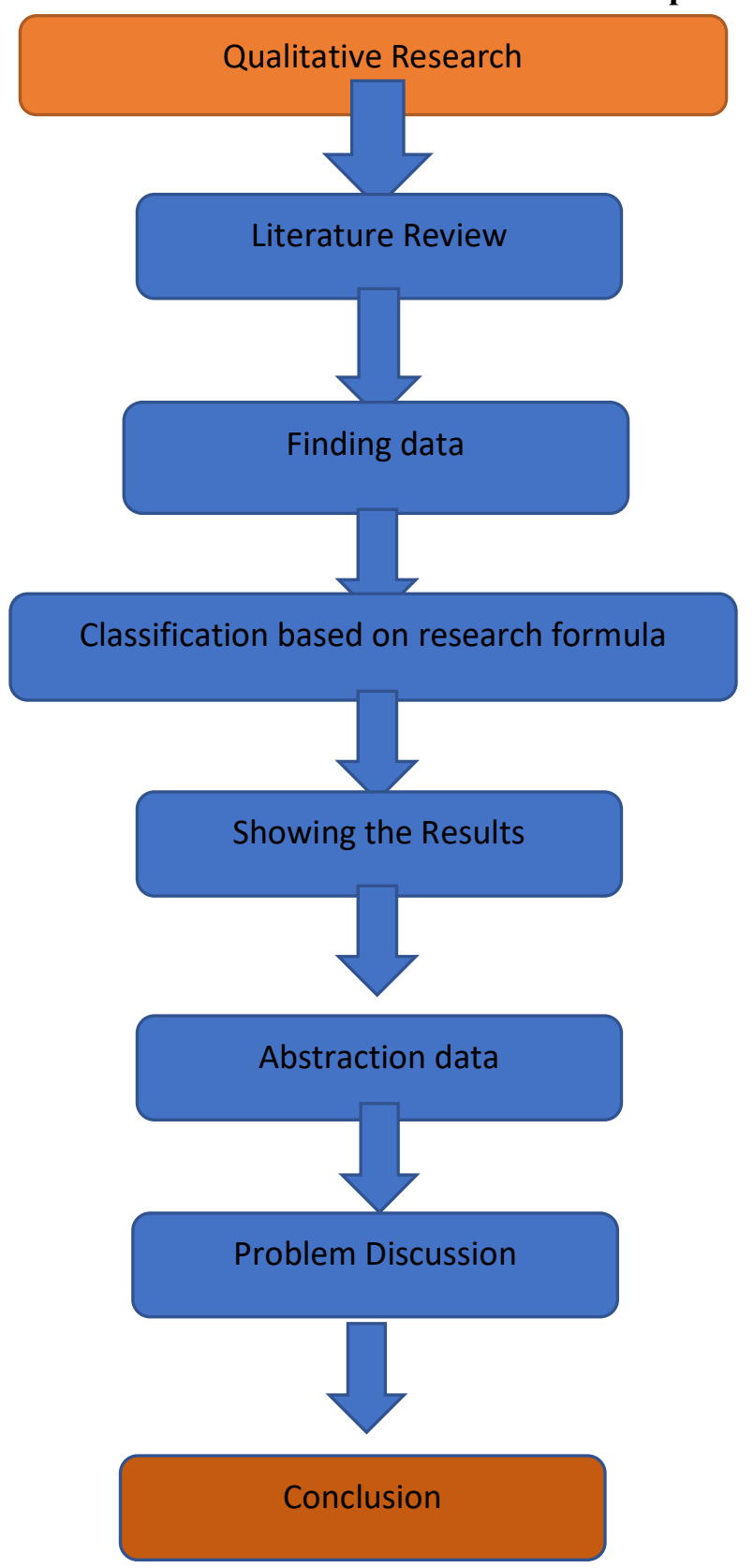


This method is used to recognize the object of the study "Indonesia's Millennial Generation Education Progress during Covid-19". To find related information, I was a writer looking for various reading materials in the form of articles that have been published online so that there is no plagiarism with the source, having sufficiently objective evidence because it has passed the review from the site to make the article public. It is related to the problem under study. The relevant data and information have been read, processed, and compiled to turn into a research report. The data that is being used is secondary data obtained from various sources that help the research topic (11).

There are several criteria that have to be met for the article. First, every article journal that is being used is from 2019-2021 in order to keep the relevancy of the topic that is happening. Second, it contains information about education nowadays, Covid-19 effects on education, and solutions for it. Third, its area must be in Indonesia and in Indonesian language to have better understanding of the study. Lastly, it should be from Google Scholar

The data that is being used is secondary data. It is obtained by searching for "Education Progress", "millennials", "and Covid-19" on the Google Scholar website for 11 article journals and news from the ministry of education that are relevant to this topic. The systematics are from sorting the author's name, title of the article, name of the journal, date of publication, volume number, issue number and lastly the location and page. For books, from the book edition, writer's name, Publisher name, and Location. This technique is used to make references that are neater and easier to read.

\section{RESULTS}

Table 2. Literature Result

\begin{tabular}{|c|l|l|l|}
\hline $\begin{array}{c}\text { Author / } \\
\text { Year of }\end{array}$ & \multicolumn{1}{|c|}{ Variables Factors Affecting } & \multicolumn{1}{c|}{ Findings } \\
\hline $\begin{array}{c}\text { (Nafirin Al, } \\
\text { Hudaidah, } \\
2021)\end{array}$ & $\begin{array}{l}\text { Qualitative approach, the } \\
\text { instrument used is data } \\
\text { obtained through } \\
\text { documents, articles and } \\
\text { news related to online } \\
\text { learning during Covid-19 }\end{array}$ & $\begin{array}{l}\text { Education, Learning, } \\
\text { Covid-19 }\end{array}$ & $\begin{array}{l}\text { Explaining obstacles that } \\
\text { happen during pandemic } \\
\text { and stating that virtual } \\
\text { learning is one of the } \\
\text { solutions for Indonesian } \\
\text { education to keep going. }\end{array}$ \\
\hline $\begin{array}{c}\text { (Herliandry et al., } \\
\text { 2020) }\end{array}$ & $\begin{array}{l}\text { Using qualitative research of } \\
\text { descriptive content analysis } \\
\text { study on online learning } \\
\text { while Covid-19 pandemic. } \\
\text { Analysis uses articles and }\end{array}$ & Learning, Pandemic, & $\begin{array}{l}\text { Online learning is an } \\
\text { effective solution for } \\
\text { schools to undergo } \\
\text { studying while pandemic } \\
\text { is there. }\end{array}$ \\
\hline
\end{tabular}




\begin{tabular}{|c|c|c|c|}
\hline Author / & Variables & Factors Affecting & Findings \\
\hline & $\begin{array}{l}\text { books of relevant or } \\
\text { previous studies. }\end{array}$ & & \\
\hline $\begin{array}{l}\text { (Kurniati E, } \\
\text { et al., 2020) }\end{array}$ & $\begin{array}{l}\text { Collecting data using a } \\
\text { sample of } 9 \text { parents that } \\
\text { have kids actively attending } \\
\text { elementary school. }\end{array}$ & $\begin{array}{l}\text { Parent roles, child, } \\
\text { pandemic era }\end{array}$ & $\begin{array}{l}\text { Parents have many } \\
\text { general roles for their } \\
\text { children to guide them } \\
\text { during school from home } \\
\text { during a pandemic. }\end{array}$ \\
\hline $\begin{array}{l}\text { (Yamin M, } \\
\text { Syahrir. } \\
\text { 2020) }\end{array}$ & $\begin{array}{l}\text { study used qualitative } \\
\text { research study literature } \\
\text { method. Uses journal } \\
\text { articles, news, literature } \\
\text { magazines about education } \\
\text { building on the "freedom } \\
\text { studying" system. }\end{array}$ & $\begin{array}{ll}\text { Freedom } & \text { studying } \\
\text { method, } & \text { teaching } \\
\text { method, } & \text { blended } \\
\text { learning. } & \end{array}$ & $\begin{array}{l}\text { Explaining the concept of } \\
\text { "freedom studying" } \\
\text { system for the needs in } \\
\text { era industry revolution } \\
4.0 \text {. }\end{array}$ \\
\hline $\begin{array}{l}\text { (Isnarmi M, } \\
\text { Febriani R, } \\
\text { 2020) }\end{array}$ & $\begin{array}{l}\text { This research used the study } \\
\text { of literature. Uses articles, } \\
\text { books, and news to find } \\
\text { social studies about the } \\
\text { millennial generation and } \\
\text { local culture. }\end{array}$ & $\begin{array}{l}\text { Social Studies } \\
\text { Education, Millennial } \\
\text { Generation, Citizens. }\end{array}$ & $\begin{array}{l}\text { Information about Social } \\
\text { Studies for the millennial } \\
\text { era either advantages or } \\
\text { disadvantages to the } \\
\text { students nowadays. }\end{array}$ \\
\hline $\begin{array}{l}\text { (Dewi WAF, } \\
\text { 2020) }\end{array}$ & $\begin{array}{l}\text { The research uses library } \\
\text { research methods. Data is } \\
\text { obtained from various kinds } \\
\text { of libraries such as } \\
\text { documents, books, } \\
\text { magazines, news that are } \\
\text { relevant to Covid-19 and } \\
\text { Online school in elementary } \\
\text { school. }\end{array}$ & $\begin{array}{l}\text { Impact of Covid-19, } \\
\text { online learning, } \\
\text { elementary school } \\
\text { environment. }\end{array}$ & $\begin{array}{l}\text { Problems in some schools } \\
\text { that cannot do online } \\
\text { learning and solutions to } \\
\text { improve the } \\
\text { effectiveness of learning. }\end{array}$ \\
\hline
\end{tabular}




\begin{tabular}{|c|c|c|c|}
\hline $\begin{array}{c}\text { Author / } \\
\text { Year of }\end{array}$ & Variables & Factors Affecting & Findings \\
\hline $\begin{array}{c}\text { (Aji RHS, } \\
\text { 2020) }\end{array}$ & $\begin{array}{l}\text { The method used is a } \\
\text { qualitative literature } \\
\text { method. By gathering data } \\
\text { about Covid-19 effect on } \\
\text { education in Indonesia on } \\
\text { schools, skills, and learning } \\
\text { process }\end{array}$ & $\begin{array}{l}\text { School, Covid-19, } \\
\text { Students, Indonesia. }\end{array}$ & $\begin{array}{l}\text { Shows information of } \\
\text { Covid-19 on school } \\
\text { productivity and } \\
\text { economy mainly the bad } \\
\text { effects of it. }\end{array}$ \\
\hline $\begin{array}{c}\text { (Wardani A, } \\
\text { Ayariza Y, } \\
\text { 2020) }\end{array}$ & $\begin{array}{l}\text { The research design was } \\
\text { descriptive qualitative. The } \\
\text { sample of this research is } 12 \\
\text { parents with children that } \\
\text { are still in kindergarten to } \\
\text { find obstacles of parents in } \\
\text { this Covid-19 situation. }\end{array}$ & $\begin{array}{l}\text { Constraints of Parents, } \\
\text { Children, Study at } \\
\text { Home, } \\
\text { Period. }\end{array}$ & $\begin{array}{l}\text { The obstacles that } \\
\text { parents went through } \\
\text { while accompanying their } \\
\text { children studying at } \\
\text { home. For example, not } \\
\text { understanding studies, } \\
\text { having a hard time } \\
\text { growing children's } \\
\text { curiosity on studying, and } \\
\text { slow internet access. }\end{array}$ \\
\hline $\begin{array}{l}\text { (Anggorowati } \\
\text { EL, et al., } \\
\text { 2020) }\end{array}$ & $\begin{array}{l}\text { Using a qualitative research } \\
\text { design. With data collection } \\
\text { techniques and library } \\
\text { documentation. Analyzing } \\
\text { character education for } \\
\text { living quality. }\end{array}$ & $\begin{array}{l}\text { Character education, } \\
\text { development goals. }\end{array}$ & $\begin{array}{l}\text { Character education has } \\
\text { a role to develop } \\
\text { student's abilities to } \\
\text { behave well, as a tool for } \\
\text { improving character, a } \\
\text { tool for filtering cultures } \\
\text { that enter both local and } \\
\text { foreign that are contrary } \\
\text { to the values of character } \\
\text { or national character. }\end{array}$ \\
\hline $\begin{array}{l}\text { (Laurensius } \\
\text { SA, 2020) }\end{array}$ & $\begin{array}{l}\text { The research design is in the } \\
\text { form of quantitative } \\
\text { methods. The instruments } \\
\text { used are articles, journals, } \\
\text { and books. Data analysis by } \\
\text { reprocessing data to become } \\
\text { information that is relevant } \\
\text { to Civic education for } \\
\text { revolutionary era 4.0. }\end{array}$ & $\begin{array}{l}\text { Challenges, Citizenship } \\
\text { Education, Revolution } \\
\text { 4.0. }\end{array}$ & $\begin{array}{l}\text { Components that are } \\
\text { important such as civic } \\
\text { knowledge, skills, } \\
\text { disposition, competence, } \\
\text { and commitment to be } \\
\text { smart and good citizens. }\end{array}$ \\
\hline $\begin{array}{l}\text { (Khasanah } \\
\text { DRAU, et al., } \\
\text { 2020) }\end{array}$ & $\begin{array}{l}\text { The research uses a } \\
\text { quantitative method with } \\
\text { questionnaires. } \\
\text { university students of UT } \\
\text { Semarang taken as }\end{array}$ & $\begin{array}{l}\text { Covid-19, Face-to-Face, } \\
\text { online learning }\end{array}$ & $\begin{array}{l}\text { Shows that } 82 \% \text { agree to } \\
\text { have online learning and } \\
\text { the other } 18 \% \text { did not } \\
\text { agree because they don't }\end{array}$ \\
\hline
\end{tabular}




\begin{tabular}{|c|l|l|l|}
\hline $\begin{array}{c}\text { Author / } \\
\text { Year of }\end{array}$ & \multicolumn{1}{|c|}{ Variables } & Factors Affecting & \multicolumn{1}{c|}{ Findings } \\
\hline & $\begin{array}{l}\text { population to see how much } \\
\text { support learning online will } \\
\text { get, also suggestion and } \\
\text { evaluation. }\end{array}$ & & $\begin{array}{l}\text { have devices like laptops } \\
\text { or computers. }\end{array}$ \\
\hline
\end{tabular}

By government rules number 4 of 2020 concerning the health protocol for each individual during the Covid-19 pandemic, which contains educational policies in the emergency period of the spread of Corona Virus Disease (Covid-19). This pandemic is significantly bad for people because activities are constrained or even stopped, especially in the Indonesian education system among teachers teaching learners being done online. Minister of Education and Culture Nadiem Anwar Makarim said learning can be done with the national curriculum, using the emergency curriculum, or simplifying the curriculum independently to overcome limitations because direct learning cannot be done (14).

One of the efforts made to secure both students and teachers is online learning. This system is non-face-to-face or virtual learning that can be done everywhere provided that you have an electronic device and a quota to carry out learning, which helps students and teachers bridge class activities.

According to the Ministry of Education and Culture, there are three continuity of teaching and learning that are not carried out in school which will have a prolonged negative impact, namely, first is the threat of dropping out of school because children are required to work because they are needed to help the family. Then, parents who have the perception of school have no results if it is not done face-to-face. Second, the decrease in learning due to access results in gaps in learning achievement with the limitations of different socio-economic conditions. Finally, trapped in violence that the teacher at home cannot detect.

There are also other obstacles to learning. First, an adaptation aspect is an obstacle because not all students can adapt directly, especially to environmental changes. If students study at school, they will follow the existing rules, but because learning is at home, they have to get used to doing school things at home (7). Second, limited internet connection. Even though the government has provided a free internet quota for all students to undergo online learning, location remains a major problem because not all places in Indonesia have a stable network, which hinders their learning. 
Dapodik (Data Pokok Pendidikan) stated that around 12 thousand schools do not have internet access in the outermost, underdeveloped, and frontier areas.

It is still a problem for some students even though online education has been running for about one year. Minister of Education and Culture Nadiem Makarim has allowed schools to do offline teaching and learning for schools that can run according to protocol. Opening face-to-face meetings may be possible for all schools, but the consent of parents and students is a different matter because if they agree, parents must be prepared that the risk of their child getting Covid-19 will be more significant. The Minister of Education, Nadiem Makariem, also said that currently, as many as $85 \%$ or 186,552 schools in Indonesia are doing online meetings and the rest are doing offline, which means that there are still many schools until this year that have not dared to reopen schools as before. Mr. Nadiem also said that out of all 23 countries in the East Asia and Pacific region, $85 \%$ of these countries had opened face-to-face schools, and Indonesia categorized on the $15 \%$, which is still partially open $(15,16)$.

Some of the advantages of online meetings are more relaxed and practical teaching and learning. Practical in the procedure from assignment to the collection. Then classes can be held flexibly by the agreement between students and teachers of class procedures and easier distribution of information due to technological sophistication. Parents are also able to monitor their children, and students can get more free time. Lastly, Technological literacy is increasing due to the continuous use of technology in real terms (2).

\section{DISCUSSION}

\section{The Effect from Government's Effort}

The learning from the home policy rooted in the Ministry of Education and Culture of the Republic of Indonesia through SE number 4 of 2020 concerning the Education policy when Covid-19 makes these millennials experience if the world is in danger but must continue to develop in education. Although positive things can be taken from the changes in Covid-19 on Indonesian Education, it cannot be denied that negative things more dominate it.

Three things put forward by the Ministry of Education and Culture regarding the prolonged negative impact, especially in the first point about dropping out of school because of parents' perceptions, this can be changed, especially with the appeal of the school institution about the transparency of the progress of children's education as well as improving online learning system so that it can prove that their child can develop even though learning from home. Second, about decreasing learning, it may be that it is 
still in the adaptation period so that there is a drastic decrease in students' achievement. However, it could also be that the school curriculum does not match the online process of studying and teaching. It must be quickly reviewed by schools and make an effective curriculum to increase student achievement. Finally, the point about domestic violence is a problem outside of school, but it is indeed a problem that is quite worrying. However, this point can be overcome with a counselling class that can be held to students and remind them that they can be reported directly to the right institution if there is violence in their homes. If you have difficulty contacting the institute, the school can be the place for initial reporting and is willing to help as much as possible for the safety of a student.

As a student in the school itself, the learning process is the best public policy for increasing knowledge, experience, and skills (5). It is a constant tradition that school is a place to socialize or make friends and build connections. Schools are also a place for direct moral character education from teachers to students, but with the existence of Covid-19, the whole tradition has changed. Character education is one of the most important aspects in creating quality human resources (9). Such as Citizenship Education to build a spirit of nationalism. There are three main aspects of civic education: civic knowledge, civic skills, and civic disposition (6). In the absence of a school to practice citizenship attitude so that it has these three main aspects, it can be done at home with family and activities other than school or at homes, such as travelling and public places. This practice is needed so that millennial citizens can have good attitudes, knowledge, and citizenship skills even when obstructed by the Covid-19 pandemic.

\section{The Problem on School Opening}

The opening of schools must be thought out carefully by all elements concerned with the educational institution because even if it is strictly maintained in school because protocol regulations are strictly guarded in the area, it will be useless if outside the Education Area it is not maintained. The spread may occur not from inside the school to the outside environment. However, the reverse is more significant because supervision in public places is more difficult than those owned by institutions or private ones. Thus, it might be better if the government continues to promote learning activities from home unless students and parents are responsible for the risks taken if they choose to have their children attend face-to-face school, so it is okay because it is their right. Then, the learning system can be opened with a hybrid system in which online meetings have a more significant number than offline meetings to keep the number of people active in public to reduce the risk of the spread of Covid-19.

When studying offline at school, a student's time is completely spent on travel, schooling, and assignments or studying, so they cannot learn anything else. With more free time because of online learning, various activities can teach things that students are invested in. So, maybe it is better to make an independent 
learning curriculum for students so that formal school learning online can be sufficient. Then they can use enough free time for hobbies, work and other activities according to students' interests.

Currently, the house is a place for student learning. Parents can do various things to help educate their children because family is one of the education centres. Many things can be done; the first is to ensure that children maintain cleanliness and health (4). The Covid-19 protocol can be practised at home with parental supervision in hygiene and health. Parents can protect the environment, food, and sleep hours so that the child does not forget that health is important. They were second, accompanying children in carrying out their activities. When there are no teachers to monitor students directly, parents can become substitutes to have someone who can be socialized directly and not feel bored or lethargic while studying. Third, provide creative things for children. Apart from only teaching formal education, children can manage their interests and talents by providing activities that can develop them.

\section{The Progress of education in the Future}

So, the development of learning in Covid-19 for millennials is already at the online and offline stages simultaneously. If seen from the impact, there will always be negative and positive sides. Therefore all students, parents, teachers, and other parties involved must be able to take responsibility for responding to the learning system. Suppose indeed the negative things are always significant. In that case, there is a way to carry out a process in a good way to continue to educate students and make them aware that learning can be done in any medium. Ultimately, education is one of the important things in life to produce something. We must make people aware that it is important to carry out education effectively and efficiently so that development is always there.

\section{CONCLUSION}

Based on the data and discussion above, it can be understood that the Covid-19 pandemic forces all sectors, especially in education, to transform instantly to bridge activities that should be done face-toface to become virtual. Kemendikbud issued this policy to keep the school community protected from viruses. However, the policy has many impacts on students, teachers, as well as families or parents. The main challenge is the socio-economy in limited facilities, different learning methods, thus reducing students' achievement. However, with activities predominantly carried out at home, parents can become substitutes for teachers at home. The Ministry of Education and Culture said that in July 2021, schools must be opened face-to-face; it is still a choice of students and parents to choose between learning to take place online or offline because it is their right as Covid-19 still has no cure. Thus, a selection of activity policies on how to adapt in this learning is all in the hands of individuals that related to the education environment, and they can choose their choice with the aim of helping the progress of education as well as the progress 
of Covid-19 so that Health and Education in Indonesia can be maintained and progressed. Based on research, literature review is a method that is enough to examine this issue to maintain safety from the pandemic, but it is impossible to do a detailed and well examined research. Thus, it is recommended if you don't have the necessary to take risk on this pandemic. Observational research and questionnaires can be carried out if possible for researchers who want to get detailed and satisfactory results.

\section{REFERENCES}

1. Wardani A, Ayariza Y. Analisis Kendala Orang Tua dalam Mendampingi Anak Belajar di Rumah Pada Masa Pandemi Covid-19. Jurnal Pendidikan Anak Usia Dini. 2021;5(1)772-782

2. Yamin M, Syahrir. Pembangunan Pendidikan Merdeka Belajar (Telaah Metode Pembelajaran). Jurnal Ilmiah Mandala Education. 2020;6(1)126-136

3. Isnarmi M, Febriani R. Social Studies: Generasi Millenial dan Kearifan Lokal. Jurnal Pendidikan Sains Sosial dan Kemanusiaan. 2020;13(1)55-66

4. Kurniati E, Alfaeni DKN, Andriani F. Analisis Peran Orang Tua dalam Mendampingi Anak di Masa Pandemi Covid-19. Jurnal Pendidikan Anak Usia Dini. 2020;5(1)241-256

5. Anggorowati EL, Shinta AAM, Nafi'ah ER, Lathif S. Peran Pendidikan Karakter Sebagai Wujud Pendidikan Berkualitas Sesuai Dengan Tujuan Sustainable Development Goals (sdgs). 2020;2(1)354-361

6. Laurensius SA. Tantangan Pendidikan Kewarganegaraan Pada Revolusi 4.0. Jurnal Ensiklopedia Social Review 2020;2(3)333-339

7. Nafrin AI, Hudaidah. Perkembangan Pendidikan Indonesia di Masa Pandemi Covid-19. Jurnal Ilmu Pendidikan. 2021;3(2)456-462

8. Khasanah DRAU, Pramudibyanto H, Barokah W. Pendidikan Dalam Masa Pandemi Covid-19. Jurnal Sinestesia. 2020;10(1)41-48

9. Herliandry LD, Nurhasanah, Suban ME, Kuswanto H. Pembelajaran Pada Masa Pandemi Covid19. Jurnal Teknologi Pendidikan. 2020;22(1)65-70

10. Aji RHS. Dampak Covid-19 Pada Pendidikan di Indonesia: Sekolah, Keterampilan, dan Proses Pembelajaran. Jurnal Sosial \& Budaya Syar-i. 2020;7(5)395-402

11. Mardawani, Praktis Penelitian Kualitatif: Teori Dasar dan Analisis Data dalam Perspektif Kualitatif. Central Java: Deepublish; 2020.

12. Rukin, Metodologi Penelitian Kualitatif: Yayasan Ahmar Cendikia Indonesia. South Sulawesi; 2019.

13. Dewi WAF, Dampak Covid-19 Terhadap Implementasi Pembelajaran Daring di Sekolah Dasar, Jurnal Ilmu Pendidikan. 2020;2(1)55-61

14. Kementerian Pendidikan dan Kebudayaan. Kemendikbud Terbitkan Kurikulum Darurat pada Satuan Pendidikan Dalam Kondisi Khusus [Internet]. August 07, 2020 [Cited May 22, 2021]. Available from: https://www.kemdikbud.go.id/main/blog/2020/08/kemendikbud-terbitkankurikulum-darurat-pada-satuan-pendidikan-dalam-kondisi-khusus

15. Tempo.Co. Banyak Sekolah Masih Daring, Menteri Nadiem: Kemauan Daerah Masih Rendah [Internet]. January 21, 2021[Cited May 21, 2021]. Available from: https://tekno.tempo.co/read/1425477/banyak-sekolah-masih-daring-menteri-nadiem-kemauandaerah-masih-rendah

16. Detiknews. Nadiem Ungkap RI Tertinggal Buka Sekolah Dibanding Negara di Asia Timur[Internet]. March 18, 2021[Cited May 21, 2021]. Available from: https://news.detik.com/berita/d-5498354/nadiem-ungkap-ri-tertinggal-buka-sekolah-dibandingnegara-di-asia-timur 